\title{
Coral Reef Sea Cucumbers in Malaysia
}

\section{Kamarul Rahim Kamarudin ${ }^{1 *}$, Aisyah Mohamed Rehan', Ahmad Lutfi Lukman ${ }^{1}$, Hajar Fauzan Ahmad ${ }^{1}$, Mohd Hanafi Anua ${ }^{1}$, Noor Faizul Hadry Nordin ${ }^{1}$, Ridzwan Hashim $^{1}$, Rosnah Hussin ${ }^{1}$, and Gires Usup ${ }^{2}$}

${ }^{1}$ Sea Cucumber (Echinodermata: Holothuroidea) Research Group, Institute of Oceanography \& Maritime Studies (INOCEM), Kulliyyah of Science, International Islamic University Malaysia, Jalan Istana, Bandar Indera Mahkota, 25200 Kuantan, Pahang Darul Makmur, Malaysia.

${ }^{2}$ Marine Microbiology \& Biotechnology Research Group, Programme of Marine Science, School of Environmental \& Natural Resource Sciences, Faculty of Science \& Technology, Universiti Kebangsaan Malaysia, 43600 UKM Bangi, Selangor Darul Ehsan, Malaysia.

*School of Biological Sciences, The University of Auckland, Private Bag 92019, Auckland 1142, New Zealand. *physique481@yahoo.co.uk (Corresponding author)

Received in $21^{\text {st }}$ October 2008, accepted in revised form $22^{\text {nd }}$ June 2009.

ABSTRACT This study aims to document species presence and distribution of sea cucumbers (Echinodermata: Holothuroidea) in Malaysia. Several coral reef habitats in Peninsular Malaysia, West Malaysia and Sabah, East Malaysia were selected as study sites. In summary, the present data showed the presence of 50 species of sea cucumbers from three orders and seven genera, with 34 species require further species identification. It was found that Order Aspidochirotida in general and genus Holothuria in particular were the major species classes. The most dominant species in Malaysia was Holothuria leucospilota. As many as 37 species were found in Sabah, 21 species were recorded in Peninsular Malaysia and 10 species were present in both regions. Of 15 Actinopyga species, 14 species recorded were from Sabah. These findings may be due to the extensive distribution of coral reefs and low level of marine pollution. However, the possibility of biogeography factors within and out of the Sunda Platform area cannot be ruled out. In contrast, low level of species diversity was observed in few study sites in Peninsular Malaysia especially in Langkawi Island possibly due to anthropogenic threats. Future studies including more study sites and molecular phylogeny are to be incorporated in order to obtain better view on the presence and distribution of sea cucumbers in Malaysia.

\begin{abstract}
ABSTRAK Kajian ini bertujuan untuk mendokumentasi kewujudan dan taburan spesis timun laut (Ekinodermata: Holothuroidea) di Malaysia. Beberapa habitat batu karang di Semenanjung Malaysia, Malaysia Barat dan Sabah, Malaysia Timur telah dipilih sebagai kawasan kajian. Sebagai rumusan, data terkini menunjukkan kehadiran 50 spesis timun laut dari tiga order dan tujuh genus di seluruh Malaysia, di mana 34 spesis memerlukan pengesahan lanjut. Order Aspidokirotida amnya dan genus Holothuria khususnya menunjukkan kehadiran spesis yang tertinggi. Holothuria leucospilota secara bandingannya adalah spesis paling dominan di Malaysia. Sebanyak 37 spesis telah dijumpai di Sabah, 21 spesis direkodkan di Semenanjung Malaysia dan 10 spesis ditemui di kedua-dua kawasan tersebut. Daripada 15 spesis Actinopyga yang direkodkan, 14 spesis adalah dari Sabah. Penemuan ini mungkin disebabkan taburan batu karang yang luas dan tahap pencemaran laut yang rendah. Walau bagaimanapun, kebarangkalian faktor-faktor biogeografi di dalam atau di luar Pentas Sunda perlu diambilkira. Sebaliknya, kepelbagaian spesis di beberapa kawasan di Semenanjung Malaysia didapati rendah terutamanya di Pulau Langkawi kemungkinan disebabkan oleh ancaman manusia. Kajian lanjut melibatkan lebih banyak kawasan kajian dan filogeni molekul akan dijalankan pada masa hadapan untuk mendapatkan gambaran lebih jelas mengenai kehadiran dan taburan timun laut di Malaysia.
\end{abstract}

Keywords: Sea cucumber, species presence, distribution, Peninsular Malaysia, Sabah. 


\section{INTRODUCTION}

Sea cucumber belongs to the phylum Echinodermata. This soft-bodied marine-dwelling echinoderm from the class Holothuroidea is unique due to the existence of evolved skeleton (i.e. ossicles or spicules) and ancient-looked respiratory system called respiratory tree possessed by few species. According to [1], the earliest fossil evidence of sea cucumbers dates from the late Silurian period, approximately 400 million years ago. Until recently, there are six valid orders of class Holothuroidea all around the world namely Apodida, Aspidochirotida, Elasipodida, Molpadiida, Dendrochirotida and Dactylochirotida, with approximately 1,430 species distributed among the orders [2]. The identification of ossicle shape has been one of the main priorities in classification of sea cucumbers into smaller groups. Closely related species are more likely to have very similar ossicles if they have recently evolved from a common ancestor [1].

In Malaysia, sea cucumbers from genera other than Stichopus e.g. Holothuria, Actinopyga, Pearsonothuria, Bohadschia, Thelenota and order Molpadiida are commonly known as bat, balat and timun laut. Stichopus species, frequently used as the main ingredients in traditional medicine (i.e. gamat oil and gamat water) especially in Peninsular Malaysia, are locally known as gamat. The same commercial name is used by Sabah and Sarawak residents. In Sabah, sea cucumbers inclusive of gamat are commercially marketed as food, and there are minor uses as fishing poison (e.g. holothurins from Holothuria atra) and in traditional medication.

Few studies related to sea cucumbers (Echinodermata: Holothuroidea) in Malaysia were reported and published until the year 2005. The studies were conducted on several coral reef habitats of Peninsular Malaysia and Sabah, East Malaysia. Most studies were done using morphological characteristics as the main approach for species identification. Among the morphological characteristics are body shape, body colour, the existence and shape of papillae on both dorsal and ventral parts of sea cucumbers. Only one study on molecular phylogeny of indigenous sea cucumbers was carried out by [3] using Randomly Amplified Polymorphisms of
DNA (RAPD) markers in order to examine the genetic diversity between and among sea cucumber species from different localities in Malaysia. Among the early studies in Malaysia on the species presence and distribution of sea cucumbers based on morphology are by [4] and later on by [5] whereby the focus region was coral reef habitats in Sabah, East Malaysia.

Surprisingly, there was no complete report on the species presence and distribution of sea cucumbers in Sarawak. However, [5] mentioned about the use of brunok, a local name for a Molpadia species from order Molpadiida as fishing bait. Such statement indirectly showed the common use of the local sea cucumbers in Sarawak as one of the best alternative baits in fishing activities. [6] reported that Brunei Darussalam, the adjacent country to Sarawak and Sabah, had shown a wide diversity of sea cucumbers on the coral reef habitats, whereby 14 morphospecies were observed. Among the species documented were Holothuria atra, Holothuria edulis and few species from genus Bohadschia by which the species were found among the coral reef habitats. The findings are also in congruence with previous studies indicating that this unique echinoderm can be found easily within the region of shallow-water coral reefs [5]. [6] also mentioned that two out of the four Bohadschia species in Brunei Darussalam were suspected new to science. Even if there was no complete species documentation of sea cucumbers in Sarawak, the documentation in Brunei Darussalam especially by [6] and [7] could give high possibility of the same or greater diversity of sea cucumbers on coral reef habitats in Sarawak. In contrast, sea cucumbers are well known among Sabah residents and the food processing industry of sea cucumbers such as beche-de-mer, trepang or dry tunics has become one of the main contributions to the economy of Sabah.

Previously, [4] found that Colochirus robustus (the synonym of Colochirus luteus) was likely to be a common species around the Bodgaya Islands in Sabah, East Malaysia. [5] Subsequently identified 23 species of sea cucumbers on Sabah coral reef habitats. Out of that, eight species have local names but without clear scientific names, whereby approximately $62.5 \%$ (i.e. five species) was represented by genus Holothuria. Stichopus, Actinopyga and Molpadia from order Molpadiida 
shared the same percentage of $12.5 \%$ (i.e. one species each). The above studies were done on Sabah coral reef habitats. Besides, [8] reported the existence of 23 species of sea cucumbers observed at few locations in Peninsular Malaysia with six undetermined species yet to be identified. Furthermore, [9] described 37 species of sea cucumbers from Peninsular Malaysia and Sabah with six species requires further species identification. In Pulau Besar, Johor Darul Takzim [10] observed three genera and seven species of sea cucumbers with four species from the genus Stichopus yet to be identified, and Stichopus was considered as the most dominant genus. [11] Subsequently published the documentation of nine species of order Dendrochirotida from the North West Coast of Borneo and Peninsular Malaysia.

The species validation of Stichopus hermanni to Stichopus horrens was highlighted by Zulfigar at.el [12] mentioning that the specimen that was thought to be Stichopus variegatus for long time in Malaysia is actually Stichopus horrens, based on its colour variation and body wall patterns. Stichopus variegatus was the old name for Stichopus hermanni. Apart from that, further efforts had been carried out to verify and validate the taxonomic status of sea cucumbers in Malaysia, e.g. an effort taken by Massin at.el [13] in describing two new species from genus Stichopus found at the Johor Marine Park, Johor Darul Takzim, Malaysia - S. ocellatus n. sp. and $S$. rubermaculosus $n$. sp. Moreover, a report on the species presence and distribution of sea cucumbers in Malaysia by Kamarul and Ridzwan [14] had indicated that a large number of undetermined species of sea cucumbers (i.e. 19 undetermined species out of total 39 species recorded) were present in Sabah. They also found that southern part of Sabah, i.e. Semporna showed the highest diversity of sea cucumbers, and they speculated that the proximity of Sabah to the Wallace's Line may be one of the factors contributing to the high diversity. The above studies indirectly suggested and revealed the unclear and problematic taxonomic status of sea cucumbers particularly in Malaysia, based on the documentation of a large number of undetermined species. In views of environmental concern, the sudden appearance of a large number of brunok from order Molpadiida along few main beach areas in Port Dickson, Negeri Sembilan including
Tanjung Gemuk beach on $5^{\text {th }}$ April 2005 about three months after the big tsunami incident on $26^{\text {th }}$ December 2004 has opened the eyes of Malaysians about the possible environmental threatens to indigenous sea cucumbers. However, until now there is still no strong experimental test explaining the real causes of such phenomenon.

Accordingly, the general objective of this study is to document species presence and distribution of sea cucumbers on several coral reef habitats of Malaysia, covering Peninsular Malaysia, West Malaysia and Sabah, East Malaysia. Findings from previous studies on sea cucumbers in Malaysia were used as comparison to the outcomes from this study. Topics on the species presence, distribution and issues related to the ecology and economic aspects were correlated and discussed. The outputs from this present study are foreseen to be main guideline in future research in Malaysia, especially for studies involving molecular techniques as additional approaches.

\section{MATERIALS AND METHODS}

\section{Study Sites}

Sea cucumbers from several coral reef habitats in Peninsular Malaysia, West Malaysia and Sabah, East Malaysia (Figure 1) were observed, photographed and sometimes collected with official permission. The samplings took place for approximately 3 years, from August 2004 until October 2007. The study sites were on intertidal zone, and most documentation was done during the low tide. No fixed or standard sampling hours were allocated for all sites. Within Peninsular Malaysia, coral reef habitats of Pangkor Island, Perak Darul Ridzuan; Tanjung Gemuk, Negeri Sembilan Darul Khusus and surrounding islands in Langkawi, Kedah Darul Aman were chosen as study sites in the West Coast region. The study sites in the East Coast region were Kapas Island, Perhentian Island and Redang Island in Terengganu Darul Iman; and Tioman Island in Pahang Darul Makmur. Two main study sites were selected in Sabah i.e. Kota Kinabalu and Tuaran in the northern part and Semporna in the southern part. Global Positioning System (GPS) was used to mark and to record the position of each sampling site (not shown specifically, refer to Figure 1). 


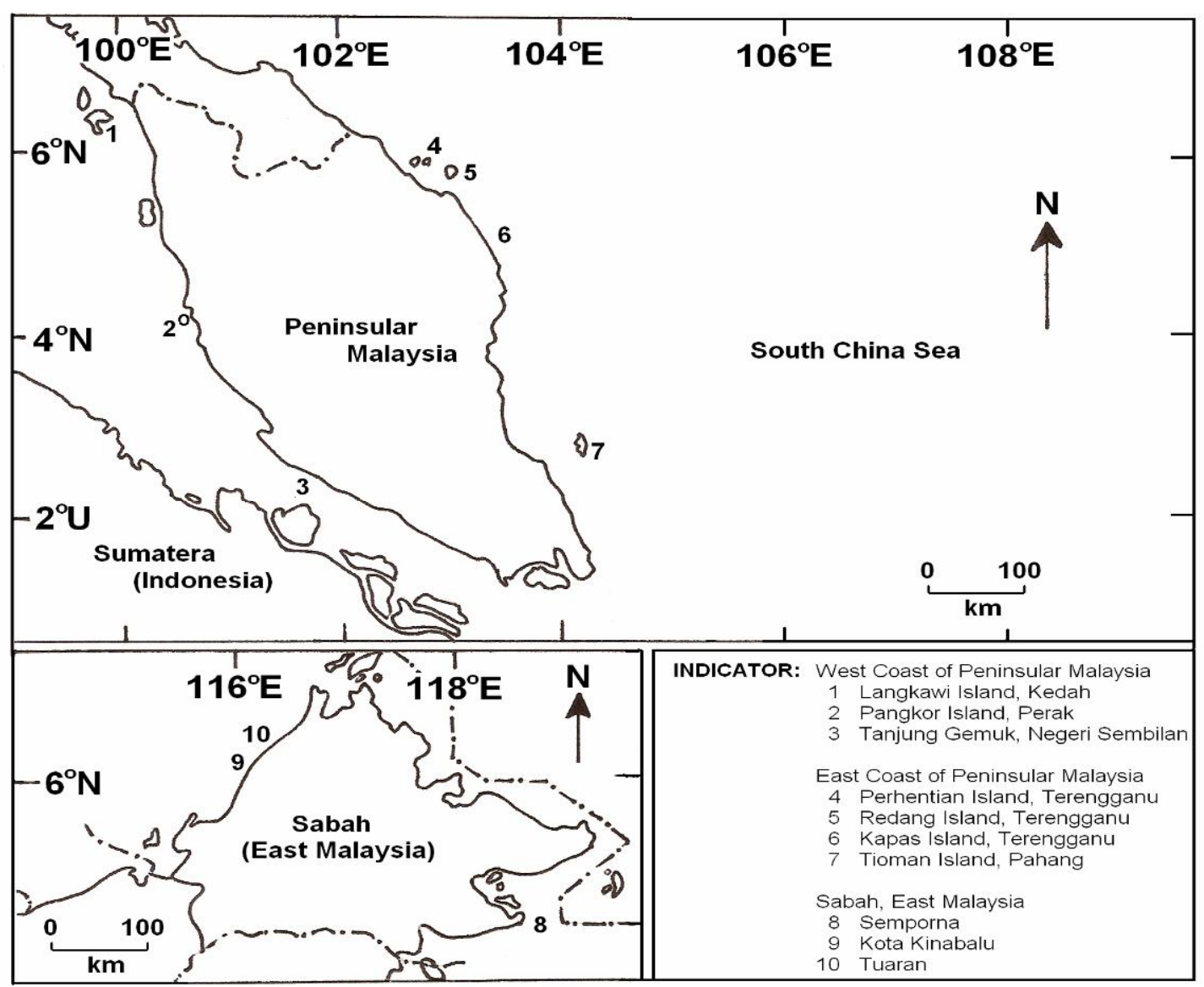

Figure 1. Study area with the 10 main sampling sites (with numbers).

\section{Sampling and Species Identification}

Sea cucumbers were sampled with the assistance of professional divers and local residents. Species identification of sea cucumbers by morphology was done by referring to the previous studies, supporting references and also through the information given by local residents. Undetermined species are designated temporarily as sp. (e.g. Stichopus sp.4; Table 1) with provided local names. Photographs were also taken as backup and further references.

\section{Storage and Preservation}

For short-term storage, fresh specimens of dead sea cucumbers were stored in ice boxes containing ice cubes or seawater during sampling. In the laboratories, specimens were transferred into $20^{\circ} \mathrm{C}$ fridge or $-80^{\circ} \mathrm{C}$ freezer for long-term storage. Specimens are also preserved in $70 \%$ ethanol, with proper cataloging.

\section{RESULTS}

As many as 50 species of sea cucumbers were found to date in several coral reef habitats of Peninsular Malaysia, West Malaysia and Sabah, East Malaysia (Table 1) with 34 species (Table 2) require further species identification. Of the total number of species, 18 species (i.e. 36\%) recorded were from genus Holothuria, indicating the highest percentage of species diversity; subsequently followed by genus Actinopyga with 15 species (i.e. 30\%), and genus Stichopus with nine species (i.e. 18\%). Percentage of $8 \%$ (i.e. four species) was shown by genus Bohadschia and $4 \%$ (i.e. two species) by genus Synapta. The lowest percentage of diversity was shared by genera of Molpadia and Pearsonothuria with 2\% each (i.e. one species each).

The present study showed that 10 species were obtainable from both Peninsular Malaysia and Sabah. In terms of undetermined species, 14 
species sampled were from genus Actinopyga, nine species from genus Holothuria, six species from genus Stichopus, two species from genera of Bohadschia and Synapta; and one species from genus Molpadia (Table 2). Interestingly, 13 undetermined Actinopyga species were found around coral reef habitats of Binawan Island, Semporna and one undetermined species was recorded in Redang Island, Terengganu Darul Iman, East Coast of Peninsular Malaysia. All the 34 undetermined species greatly need further verification based on ossicle characters, behaviour and molecular phylogeny. It is foreseen that a small number of the undetermined species, especially among Actinopyga species observed in Sabah, are new species. With respect to biogeography, the proximity of Sabah region to the Wallace's line may contribute to such possible phenomenon.

In the West Coast of Peninsular Malaysia, low level of sea cucumber diversity was measured around the coral reef habitats of Pangkor Island, Perak Darul Ridzuan and surrounding islands in Langkawi, Kedah Darul Aman. Only three species - Holothuria leucospilota, Holothuria atra and bat hati or brunok from order Molpadiida - were observed in Langkawi after two surveys, e.g. around Selat Bagan Pauh, Tanjung Pandan and Intan Besar Island (previously known as Kentut Besar Island); while only Stichopus horrens and Holothuria leucospilota were documented on coral reef habitats of Teluk Nipah and Pasir Bogak, Pangkor. However, the individual number of Stichopus horrens was recorded high around Teluk Cina, Pasir Bogak in Pangkor. In contrast, coral reef habitats of the East Coast, for instance in Terengganu Darul Iman, indicated higher diversity level of sea cucumber (i.e. 11 species), including the findings of eight undetermined species. Furthermore, higher diversity level of sea cucumbers was also shown by Tioman Island, Pahang Darul Makmur. Tioman Island indicated the existence of 15 species of sea cucumbers including seven undetermined species requiring further species identification.

\section{DISCUSSION}

Generally, the process of establishing taxonomic update for sea cucumbers (Echinodermata: Holothuroidea) in Malaysia was challenging but progressive with the continuous and consecutive attempts by local scientists and outsiders. The taxonomic revision has become more challenging with the current findings of 34 undetermined species in Malaysia, as well as the previous findings [5], [8], [10] and [13]. In spite of that, the present study along with previous research are likely manageable to provide up-to-date view of species presence and distribution of sea cucumbers in Malaysia, making such update the head start for subsequent future research, particularly in using molecular approaches to revise the taxonomic validity. In fact, organism groups with well-known taxonomies are important to ease the difficulties in listing existing species in a population [15].

In total, three orders of sea cucumbers were currently found in Malaysia i.e. Aspidochirotida, Molpadiida and Apodida; with seven genera and 50 species distributed among the orders. The present findings showed high diversity of sea cucumber in Malaysia. The total number of species recorded is higher than the records by [9], whereby they described 37 species with six species requiring further species identification. The presence of other species had also been recorded previously, [11] recorded the presence of nine species from order Dendrochirotida from the North West Coast of Borneo and Peninsular Malaysia. Furthermore, Colochirus robustus (the synonym of Colochirus luteus) was likely to be a common species around the Bodgaya Islands in Sabah, East Malaysia [16]. Apart from that, [8] recorded the presence of other species in Malaysia such as Thelenota ananas, Actinopyga echinites, Actinopyga miliaris, Synapta recta and Stichopus hermanni (formerly known as Stichopus variegatus). Some local residents also claimed the presence of large conspicuous Thelenota anax and other Synaptids (e.g. Synapta maculata and Euapta godeffroyi) on Malaysian coral reef habitats. Besides, Siti et al. [10] documented three genera and seven species of sea cucumber in Besar Island, Johor Darul Takzim with four species from the genus Stichopus yet to be identified. As the species identification became complicated, further effort had been taken by Massin et al. [13] in describing two new species from genus Stichopus found at the Johor Marine Park, Johor Darul Takzim, Malaysia - Stichopus ocellatus n. sp. and Stichopus rubermaculosus $n$. 
$s p$. Accordingly, it is estimated that more than 80 species of sea cucumbers are present in Malaysia.

In the present study, the greatest diversity of sea cucumbers was shown by order Aspidochirotida. This finding is supported by Ridzwan [5] and Baine [8] who identified five genera of order Aspidochirotida namely Holothuria, Stichopus, Thelenota, Bohadschia and Actinopyga - making this order the most abundant and in the front rank of top species diversity within Malaysian coral reef habitats. As there are many previous research and personal comments showing the presence of other species such as Thelenota anax, Thelenota ananas, Stichopus hermanni, and species from order Dendrochirotida [11] that were not recorded in the present study, further research especially on molecular approaches and more study sites including Sarawak, East Malaysia need to be included in the future. Recent developments in DNA research could ease the difficulties in identifying closely related species when traditional characters have been proven inconclusive [1]. In general, current species abundance of sea cucumbers in Malaysia has displayed patchiness, even if it was relatively high in few study sites.

In Sabah, East Malaysia comprising Bodgaya and Ligitan groups of islands, the coral reef formation is well-developed in seawater region of Sulawesi Sea [17]. Coral reef area in tropical region is the best habitat for sea cucumbers due to the abundant source of organic particles as food [5]. Both statements are in congruence with the current findings of diverse species of sea cucumbers on coral reef habitats of Semporna, Sabah e.g. in Maiga Island (part of Bodgaya group) and Mabul Island (part of Ligitan group). Such uniqueness and privilege have made Sabah the most significant state in Malaysia for sea cucumber fisheries, with the dominant product from processing is beche-de-mer. Around 155 tonnes of sea cucumbers were landed in 1995 as estimated by the Sabah Fisheries Department, by which a wide variety of species are targeted mainly for food industry of beche-de-mer in Sabah. The current observation of 37 species inclusive of 13 undetermined Actinopyga species in Sabah also indicated that Sabah in general and Semporna in particular had the best and the most interesting species diversity of sea cucumbers in Malaysia.
Relatively, the number of Actinopyga species currently recorded was larger in comparison with the overall findings by [5], [8] and [9]. Furthermore, [8] recorded the existence of two Synapta species (i.e. Synapta recta and Synapta sp.1) in Tioman Island and Payar Island, Langkawi. These showed that Synaptids were also present in both Peninsular Malaysia and Sabah. On top of that, proper management of marine park zone, e.g. Tunku Abdul Rahman Park, Kota Kinabalu may have also contributed to the great species richness in Sabah. Recreational zone and reserve zone are being implemented in coral reef habitat of Manukan Island, Kota Kinabalu, Sabah for instance in order to ensure that the gene pool is retained while the eco-tourism is developing. However, some issues brought by [18] pertaining to the lack of manpower in Sabah Fisheries Department and weak monitoring procedures require great concern and immediate action in developing a workable strategy towards management of sea cucumber fisheries.

With respect to biogeography, the proximity of Sabah region to the Wallace's line may also contribute to the high level of species presence and distribution of sea cucumbers on Sabah coral reef habitats. It is postulated that sea cucumber species from both Oriental and Australian regions may have mingled within the Wallace's line, causing the high species diversity within Sabah coral reef habitats. However, the existing data are still considered inadequate and further studies are greatly needed in the future for better view and confirmation. It is further postulated that the connection of Peninsular Malaysia to Sabah, East Malaysia by Sunda Shelf during the Pleistocene maximum lowering of seawater [19] has led to the relatively high difference of species diversity between the two regions, as indicated mainly by species from genus Actinopyga.

There was no clear and up-to-date information on the distribution of sea cucumbers in Sarawak, East Malaysia. Biogeographically, Sarawak is situated close to the lowland centre of historic Sunda Platform. According to Ho S.L [20], the growth of coral reefs in seawater region of Sarawak, East Malaysia e.g. coral reef habitats surrounding Talang-Talang Besar Island, Talang-Talang Kechil Island, Sampadi Island, Satang Besar Island and Satang Kechil Island were limited due 
to the high turbidity and influx of fresh water from the rivers of Sarawak mainland. The developments in tourism as well as the proximity of surrounding islands to the mainland have also worsened the condition. Only the use of brunok from order Molpadiida as fishing bait among Sarawak residents was mentioned by Ridzwan [5]. In Sabah, brunok is commonly known as bat hati (Table 1). In Brunei Darussalam, Lane [6] reported a wide diversity of sea cucumbers on the coral reef habitats, whereby 14 species were observed. Holothuria atra, Holothuria edulis and species from genus Bohadschia were among the species present on Brunei Darussalam coral reef habitats. However, it was mentioned that the sources of sea cucumbers in Brunei Darussalam are not fully explored and relatively unexploited as compared to most Indo-Pacific reef habitats [7]. Furthermore, Lane [6] also stated that two of the four Bohadschia species in Brunei Darussalam were considered new to science. This finding seems further strengthening the proposal that new species could be present on the coral reef habitats of Borneo Island. As Brunei Darussalam is situated next to Sarawak and Sabah within the Borneo Island, it is foreseen that Sarawak may have the same or greater diversity of sea cucumber, even if some observation [17] could be a major contribution to low species diversity.

There are two main regions of coral reefs in Peninsular Malaysia - the East Coast and the West Coast. In present study, the level of sea cucumber diversity in the West Coast of Peninsular Malaysia was considered low, due to the small number of sea cucumber species currently observed in Pangkor Island, Perak Darul Ridzuan; Tanjung Gemuk, Negeri Sembilan Darul Khusus and Langkawi Island, Kedah Darul Aman. Only four species were documented - Stichopus horrens, Holothuria atra, Holothuria leucospilota and bat hati from order Molpadiida. [8] showed the almost similar records as from this present study about the species presence in Pangkor Island. However, local residents in Pangkor Island claimed that other species like Stichopus chloronotus, Thelenota ananas and an undetermined Stichopus species were also present on the coral reef habitats of Pangkor Island, Perak Darul Ridzuan. Stichopus horrens was rare at Langkawi Island as supported by [9] but the individual number of the same species was recorded high in this study around Pasir Bogak, Pangkor. As a result, Stichopus horrens has become the major target by a fisher of Pangkor Island for gamat oil and gamat water, as stated by [18]. However, the latter statement is contrary to other findings [8] that mentioned the presence of Stichopus hermanni (previously accepted as Stichopus variegatus) instead. There are also other statements mentioned by [8] contradicting with [18]. It is believed that [18] had made verification and correction to the species identification by [8], as [21] further verified the findings from [18]. Furthermore, [20] found that the distribution of coral reefs along the West Coast of Peninsular Malaysia was deemed poor and the underwater visibility was not good; and these findings were likely related to the low level of sea cucumber diversity currently observed in the West Coast region. Such statement was further supported by [18] referring to the regular importation of sea cucumbers from Adang, Thailand during the 1990s. Limited coral growth is believed to affect the marine-living organisms such as sea cucumbers that depend on the coral reefs as main habitat and food source. Likewise, the present observation also revealed the poor distribution of coral reefs on few coral reef habitats of Peninsular Malaysia, especially in Langkawi Island, possibly due to the negative impacts originated from anthropogenic threats. Direct exploitation, introduced species, extinction cascades, habitat loss and degradation are factors leading to species declines [22]. Hence, it is clear that coral reef destruction is proportional to the reduction of species richness and ecological diversity of sea cucumbers. [9] found that Stichopus horrens was rare at Langkawi Island, supporting the possibility of declination in sea cucumber processing and trade industry of the traditional fishery site. In order to help maintaining the stock for sea cucumber trade in Langkawi, [18] suggested that the demand in Langkawi may be supplied from three directions: from within through restocking initiatives, from Thailand in a trade agreement and from Pangkor Island, Perak Darul Ridzuan, Malaysia as part of a managed fishery. Interestingly, Payar Island within Langkawi group showed the presence of 10 species [8] thus making it the prospective study site in future studies. 
Until nowadays, sea cucumbers are not included in the list of endangered species in Malaysia, neither it is considered endangered by the World Conservation Union (IUCN) which maintains a global list of endangered species. In terms of the conservation of sea cucumber in Malaysia, [23] emphasized the need to support the inclusion of sea cucumber species from the families of Holothuridae and Stichopodidae into the Appendices of the Convention on International Trade in Endangered Species of Wild Fauna and Flora (CITES) as protected species. They suggested that few considerations must be addressed and put into account before such inclusion is made especially issues pertaining to legislation and administration, the status of sea cucumber as a protected species, and research into the status and level of exploitation of sea cucumber resources.

In contrast, the present observation on the diversity level of sea cucumbers in the East Coast region was higher in comparison with the West Coast region. [8] reported the presence of 19 species of sea cucumber in Tioman Island and they found that the high diversity was due to the absence of runoff from rivers along that coast resulting much more diverse and developed coral communities. In future studies, several coral reef habitats in the East Coast of Peninsular Malaysia are to be incorporated to get better up-to-date view of sea cucumber distribution along the region. It is strongly believed that the East Coast region will show greater diversity of sea cucumbers in future studies, based on the fact that the surrounding islands especially Redang Island is currently the main coral reef of the East Coast of Peninsular Malaysia [17].

Furthermore, few species recorded by [5] had also been validated in this study due to wrong morphological identification, for instance Bohadschia sp.1 to Actinopyga lecanora, and Stichopus variegatus Semper, 1868 to Stichopus hermanni. It is also foreseen that there is high possibility of new species existence throughout coral reef habitats in Malaysia. Undetermined species observed and listed by [5], [8], [10], [13] and [14] are likely supporting the latter proposal and prediction. In fact, the greatest diversity of floras and faunas is found in the tropical region [24], placing tropical countries including Malaysia in the front rank of top 12 megadiversity countries in the world.

\section{SUMMARY}

In summary, the present study showed the presence of three orders of sea cucumber (Echinodermata: Holothuroidea) in Malaysia comprising seven genera and 50 species. Order Aspidochirotida had shown the highest diversity of sea cucumbers (i.e. 47 species; 94\%). Large number of diverse sea cucumber species was recorded in Sabah (i.e. 37 species) while Peninsular Malaysia indicated the presence of 21 species. Furthermore, 10 species were obtainable from both regions. Biogeographical factors may have influenced the high diversity of sea cucumber observed on Sabah coral reef habitats, due the proximity of Sabah to the Wallace's line. Within Peninsular Malaysia, the East Coast region indicated higher species diversity than the West Coast region. Pollution originated from anthropogenic threats is suspected to be the main cause of lower species diversity of sea cucumbers in the West Coast Region, Peninsular Malaysia. Relatively Holothuria leucospilota was found to be the most abundant species of sea cucumber in Malaysia. Two Synapta species from order Apodida were observed only in Sabah, East Malaysia; however the previous studies showed that Synaptids were also present in Peninsular Malaysia. Previous research could not be found to update and subsequently to revise the distribution and taxonomic validity of brunok as well as other species of sea cucumbers on coral reef habitats of Sarawak, East Malaysia. Besides, the present data also indicated that in total 34 out of 50 species of sea cucumbers found in Malaysia are undetermined (Table 2). Most of the species are currently identified based on local names (Table 1). The 34 undetermined species are to be further verified and updated, morphologically and genetically in order to see the possibility of new species existence within the coral reef habitats of Malaysia.

\section{ACKNOWLEDGEMENTS}

Special thanks to all reviewers of this paper, Department of Museums and Antiquities Malaysia (i.e. Mrs. Farizawati Sabri, Mr. Mohd Khairill Jemangin \& Mr. Ardi Asmera Saeman), Marine 
Park Section, Department of Fisheries as well as Institute of Oceanography and Maritime Studies (INOCEM), Kulliyyah of Science, International Islamic University Malaysia (IIUM) for the great support. Many thanks also to all the postgraduate students at Universiti Kebangsaan Malaysia, Bangi, Selangor Darul Ehsan and our colleagues, especially to Mr. Muhammad Salleh, Br. Mohd Nahar Mohammad, Br. Azizul Abdul Aziz and Br. Ahmad Faezal Ayob for their continuous helps, advice and ideas. This research was supported by IIUM Short-term Research Grant ST43 award.

\section{REFERENCES}

1. Lambert P. (1997). Sea Cucumbers of British Columbia, Southeast Alaska and Puget Sound. UBC Press, British Columbia, pp. 2-14.

2. Kerr A.M. and Kim J. (2001). Phylogeny of Holothuroidea (Echinodermata) inferred from morphology. Zoological Journal of the Linnean Society 13: 63-81.

3. Norazila K.S., Patimah I.R. \& Ridzwan B.H. (2000). Variasi Genetik Bagi Populasi Timun Laut Di Malaysia. In Proceeding Seminar IRPA RMK7 20-22 October 2000, Melaka, pp. 464-467.

4. George J.D. and George J. (1987). The coral reefs of the Bodgaya Islands (Sabah: Malaysia) and Pulau Sipadan. 4. Macroinvertebrates. Malayan Nature Journal 40 (3 \& 4): 225-260.

5. Ridzwan B.H. (1993). Sumber Makanan Persisiran Laut Sabah. Dewan Bahasa dan Pustaka, Kuala Lumpur, pp. 149-188.

6. Lane D.J.W. (2005). Sea cucumber diversity and resources in Brunei, Borneo Island. SPC Beche-de-mer Information Bulletin 22: 57-58.

7. Lane D.J.W. (2004). Sea cucumber diversity and resources in shallow waters of Brunei, Borneo Island. SPC Beche-de-mer Information Bulletin 19: 62.

8. Baine M. and Forbes B. (1998). The taxonomy and exploitation of sea cucumbers in Malaysia. SPC Beche-de-mer Information Bulletin 10: 2-7.

9. Forbes B. and Ilias Z. (1999). The taxonomy and ecology of sea cucumbers in Malaysia. SPC Beche-de-mer Information Bulletin 12: 5.

10. Siti Z.R.S., Zulfigar B.Y. and Aileen T.S.H. (1999). Species of sea cucumber found in Pulau Besar, Johor, with special emphasis on the genus Stichopus. SPC Beche-de-mer Information Bulletin 12: 4.

11. Lane D., Marsh L.M., Vandenspiegel D. and Rowe F.W.E. (2000). Echinoderm fauna of the South China Sea: an inventory and analysis of distribution patterns. The Raffles Bulletin of Zoology Supplement 8: 459-493.

12. Zulfigar Y., Ailen T.S.H. and Siti Z.R.B. (2000). Confusion on the morphotypes of Stichopus variegatus in the South China Sea. SPC Beche-de-mer Information Bulletin 13: 39.

13. Massin C., Zulfigar Y., Hwai T.S. and Boss S.Z.R. (2002). The genus Stichopus (Echinodermata: Holothuroidea) from the Johore Marine Park (Malaysia) with the description of two new species. Bull. Kon. Belg. Inst. Natuurwet. Biologie, Brussel, Belgium, pp. 73-99.

14. Kamarul R.K. and Ridzwan B.H. (2005). Distribution and Taxonomic Revision of Sea Cucumbers (Echinodermata: Holothuroidea) in Several Populations of Malaysia. In Proceeding International Conference on Biogeography and Biodiversity: Wallace in Sarawak- 150 Years Later, jointly organized by Institute of Biodiversity and Environmental Conservation (IBEC) and Faculty of Resource Science and Technology, Universiti Malaysia Sarawak (UNIMAS), 1315 July 2005, Sarawak Tourism Centre, Kuching, Sarawak, Malaysia, pp. 225.

15. Lévêque C. and Mounolou J.C. (2003). Biodiversity. John Wiley \& Sons Ltd., England, pp. 26-49.

16. George J.D. and George J. (1987). The coral reefs of the Bodgaya Islands (Sabah: Malaysia) and Pulau Sipadan. 4. Macroinvertebrates. Malayan Nature Journal 40 (3 \& 4): 225-260.

17. Ho S.L. (1992). Coral reefs of Malaysia. Tropical Press Sdn. Bhd., Kuala Lumpur, pp. 3-11, 117-119.

18. Baine M. and Sze C.P. (1998). Sea cucumber fisheries in Malaysia, towards a conservation strategy. SPC Beche-de-mer Information Bulletin 12: 6-10.

19. Mohsin A.K.M. and Ambak M.A. (1991). Ikan Air Tawar Di Semenanjung Malaysia. Dewan Bahasa dan Pustaka, Kuala Lumpur, pp. 6-7. 
20. Ho S.L. (1992). Coral reefs of Malaysia. Tropical Press Sdn. Bhd., Kuala Lumpur, pp. 3-11, 117-119.

21. Sze C.P. and Williams N.J. (2004). Fisheries, trade and utilisation of sea cucumbers in Malaysia. SPC Beche-de-mer Information Bulletin 19: 5-6.

22. Gaston K.J. and Spicer J.I. (2004). Biodiversity: An Introduction. $2^{\text {nd }}$ ed. Blackwell Science Ltd., United Kingdom, pp. 116-130.

23. Mohd N.B. and Zahaitun M.Z. (2004). Position statement on the inclusion of species of sea cucumber from the families of Holothuridae and Stichopodidae into the
Appendices of the Convention on International Trade in Endangered Species of Wild Fauna and Flora (Cites). Maritime Institute of Malaysia (MIMA): 1-5.

24. Mittermeier R.A. (1988). Primate Diversity and the Tropical Forest: Case Studies from Brazil and Madagascar and the Importance of the Megadiversity Country. In: Biodiversity (eds. E.O. Wilson E.O. and Peter F.M.). National Academy Press, Washington D.C., pp. 145-154. 
Malaysian Journal of Science 28 (2): 171- 186 (2009)

Table 1. List of sea cucumbers from Malaysia.

\begin{tabular}{|c|c|c|c|c|c|c|}
\hline Order & No & Species & $\begin{array}{l}\text { Local } \\
\text { Name }\end{array}$ & $\begin{array}{c}\text { Peninsular } \\
\text { Malaysia }\end{array}$ & Sabah & Status \\
\hline \multirow[t]{31}{*}{ Aspidochirotida } & 1 & $\begin{array}{l}\text { Holothuria (Mertensiothuria) } \\
\text { Leucospilota, Brandt, } 1835\end{array}$ & Bat puntil & $\mathrm{x}$ & $\mathrm{x}$ & Abundant \\
\hline & 2 & $\begin{array}{l}\text { Holothuria (Metriatyla) scabra } \\
\text { Jaeger, } 1833\end{array}$ & Bat putih & & $\mathrm{x}$ & Rare \\
\hline & 3 & $\begin{array}{l}\text { Holothuria (Thymiosycia) } \\
\text { impatiens Forskal, } 1775\end{array}$ & Bat brown & & $\mathrm{x}$ & Common \\
\hline & 4 & $\begin{array}{l}\text { Holothuria(Halodeima) atra } \\
\text { Jaeger, } 1833\end{array}$ & Bat hitam & $\mathrm{x}$ & $\mathrm{x}$ & Common \\
\hline & 5 & $\begin{array}{l}\text { Holothuria(Haloidema) edulis } \\
\text { Lesson, } 1830\end{array}$ & $\begin{array}{l}\text { Bat senjata } \\
\text { anjing }\end{array}$ & $\mathrm{x}$ & $\mathrm{x}$ & Common \\
\hline & 6 & $\begin{array}{l}\text { Holothuria (Microthele) } \\
\text { fuscogilva, Cherbonnier, } 1980\end{array}$ & Bat susu & & $\mathrm{x}$ & Rare \\
\hline & 7 & $\begin{array}{l}\text { Holothuria (Thymiosycia) hilla } \\
\text { Lesson, } 1830\end{array}$ & Bat & $\mathrm{x}$ & & Common \\
\hline & 8 & $\begin{array}{l}\text { Holothuria (Microthele) } \\
\text { fuscopunctata, Jaeger, } 1833\end{array}$ & Bat & & $\mathrm{x}$ & Rare \\
\hline & 9 & $\begin{array}{l}\text { Holothuria (Acanthotrapeza) } \\
\text { coluber }\end{array}$ & $\begin{array}{c}\text { Bat } \\
\text { sumping }\end{array}$ & $\mathrm{x}$ & $\mathrm{x}$ & Common \\
\hline & 10 & $\begin{array}{l}\text { Holothuria (Theelothuria) } \\
\text { notabilis }\end{array}$ & Bat & $\mathrm{x}$ & & Common \\
\hline & 11 & Holothuria sp.4 & Bat & $\mathrm{x}$ & & Common \\
\hline & 12 & Holothuria sp.6 & Bat kasut & & $\mathrm{x}$ & Common \\
\hline & 13 & Holothuria sp.7 & Bat & $\mathrm{x}$ & & Common \\
\hline & 14 & Holothuria sp. 8 & Bat & $\mathrm{x}$ & & Common \\
\hline & 15 & Holothuria sp.9 & Bat & $\mathrm{x}$ & & Rare \\
\hline & 16 & Holothuria sp.11 & Bat & $\mathrm{x}$ & & Common \\
\hline & 17 & Holothuria sp. 12 & Bat & $\mathrm{x}$ & & Rare \\
\hline & 18 & Holothuria sp.13 & Bat putan & & $\mathrm{x}$ & Common \\
\hline & 19 & Bohadschia argus, Jaeger, 1833 & Bat & & $\mathrm{x}$ & Rare \\
\hline & 20 & $\begin{array}{l}\text { Bohadschia vitiensis, } \\
\text { Semper } 1868\end{array}$ & Bat nangka & $\mathrm{x}$ & $\mathrm{x}$ & Rare \\
\hline & 21 & Bohadschia sp.1 & Bat & $\mathrm{x}$ & & Rare \\
\hline & 22 & Bohadschia sp.2 & Bat & $\mathrm{x}$ & & Rare \\
\hline & 23 & $\begin{array}{l}\text { Actinopyga lecanora, } \\
\text { Jaeger } 1833\end{array}$ & Bat puyuh & & $\mathrm{x}$ & Common \\
\hline & 24 & Actinopyga sp. 2 & Bat timpu & & $\mathrm{x}$ & Rare \\
\hline & 25 & Actinopyga sp.3 & Bat timpu & & $\mathrm{x}$ & Rare \\
\hline & 26 & Actinopyga sp.5 & Bat timpu & & $\mathrm{x}$ & Rare \\
\hline & 27 & Actinopyga sp.6 & Bat timpu & & $\mathrm{x}$ & Rare \\
\hline & 28 & Actinopyga sp.7 & Bat timpu & & $\mathrm{x}$ & Rare \\
\hline & 29 & Actinopyga sp.8 & Bat timpu & & $\mathrm{x}$ & Rare \\
\hline & 30 & Actinopyga sp.9 & Bat timpu & & $\mathrm{x}$ & Rare \\
\hline & 31 & Actinopyga sp.10 & Bat timpu & & $\mathrm{x}$ & Rare \\
\hline
\end{tabular}


Malaysian Journal of Science 28 (2): 171- 186 (2009)

Table 1. (Continued)

\begin{tabular}{|c|c|c|c|c|c|c|}
\hline & 32 & Actinopyga sp.11 & Bat timpu & & $\mathrm{x}$ & Rare \\
\hline & 33 & Actinopyga sp.12 & Bat timpu & & $\mathrm{x}$ & Rare \\
\hline & 34 & Actinopyga sp.13 & Bat timpu & & $\mathrm{x}$ & Rare \\
\hline & 35 & Actinopyga sp.14 & Bat timpu & & $\mathrm{x}$ & Rare \\
\hline & 36 & Actinopyga sp.15 & Bat timpu & $\mathrm{x}$ & & Rare \\
\hline & 37 & Actinopyga sp.16 & Bat timpu & & $\mathrm{x}$ & Rare \\
\hline & 38 & $\begin{array}{l}\text { Pearsonothuria graeffei, } \\
\text { Semper } 1868\end{array}$ & Bat & & $\mathrm{x}$ & Common \\
\hline & 39 & $\begin{array}{l}\text { Stichopus chloronotus } \\
\text { Brandt, } 1835\end{array}$ & $\begin{array}{l}\text { Talifan varieti } \\
\text { hitam }\end{array}$ & $\mathrm{x}$ & $\mathrm{x}$ & Common \\
\hline & 40 & $\begin{array}{l}\text { Stichopus horrens } \\
\text { Selenka, } 1867\end{array}$ & Gamat & $\mathrm{x}$ & $\mathrm{x}$ & Common \\
\hline & 41 & $\begin{array}{l}\text { Stichopus ocellatus } \\
\text { Semper, } 1868\end{array}$ & Gamat & $\mathrm{x}$ & $\mathrm{x}$ & Rare \\
\hline & 42 & Stichopus vastus & Gamat & $\mathrm{x}$ & $\mathrm{x}$ & Common \\
\hline & 43 & Stichopus sp.1 & Kumbatas & & $\mathrm{x}$ & Rare \\
\hline & 44 & Stichopus sp.2 & Kambatan & & $\mathrm{x}$ & Common \\
\hline & 45 & Stichopus sp.3 & Gamat & & $\mathrm{x}$ & Rare \\
\hline & 46 & Stichopus sp.6 & Bat & $\mathrm{x}$ & & Rare \\
\hline & 47 & Stichopus sp.7 & Gamat & $\mathrm{x}$ & & Rare \\
\hline Molpadiida & 48 & Molpadia sp.1 & $\begin{array}{l}\text { Bat hati/ } \\
\text { Brunok }\end{array}$ & $\mathrm{x}$ & $\mathrm{x}$ & Common \\
\hline Apodida & 49 & Synapta sp.1 (s) & Taliaga & & $\mathrm{x}$ & Common \\
\hline & 50 & Synapta sp.2 (s) & Taliaga & & $\mathrm{x}$ & Common \\
\hline
\end{tabular}


Table 2. List of 34 undetermined species of sea cucumbers from Malaysia.

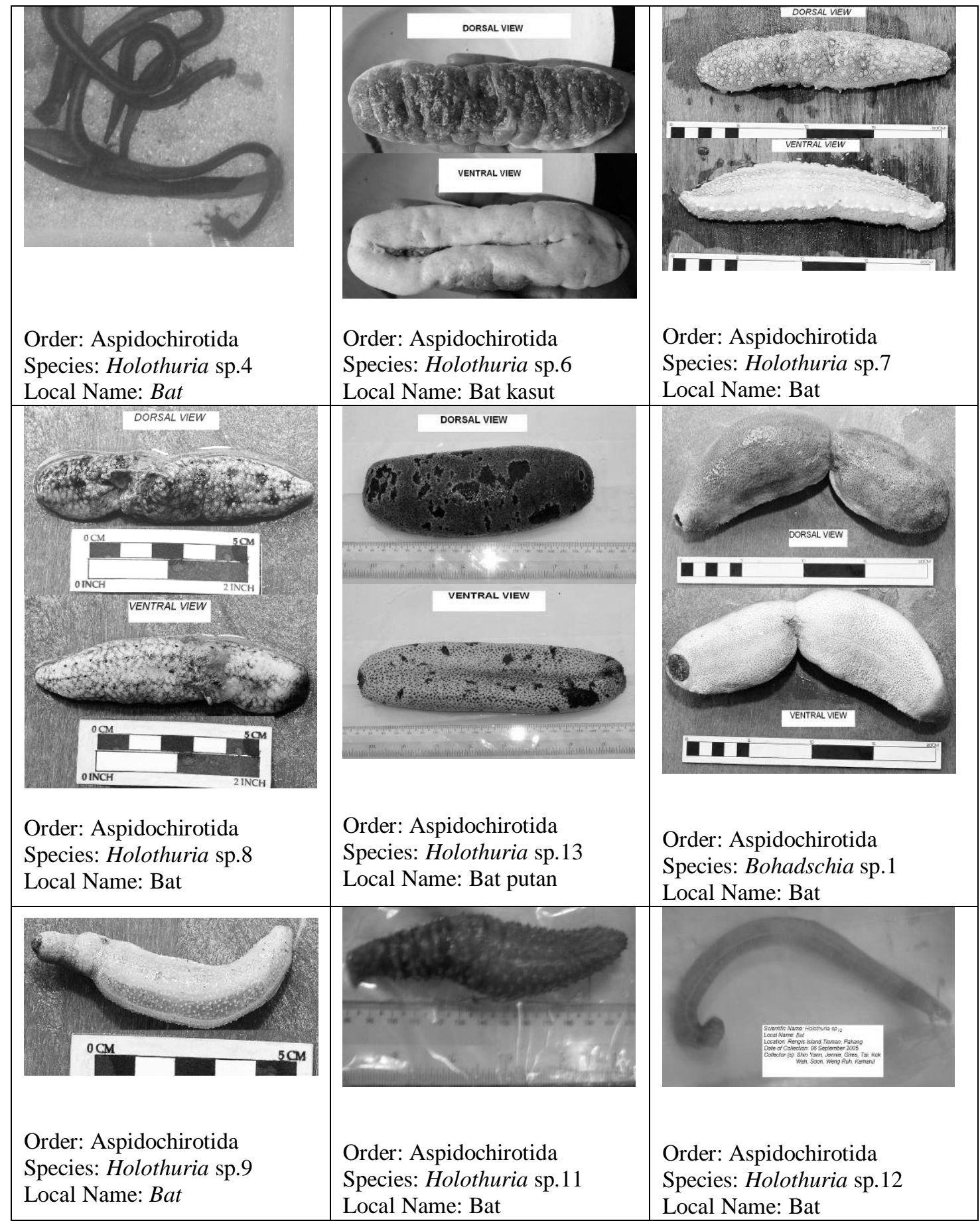




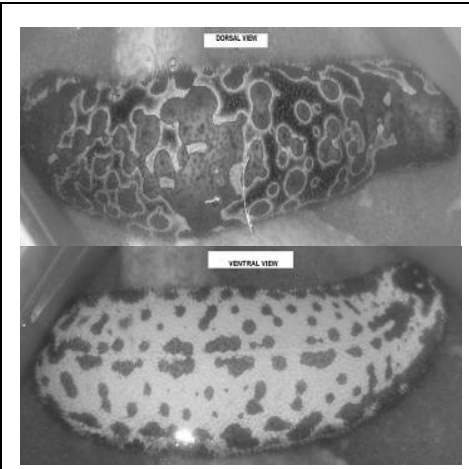

Order: Aspidochirotida Species: Bohadschia sp.2 Local Name: Bat

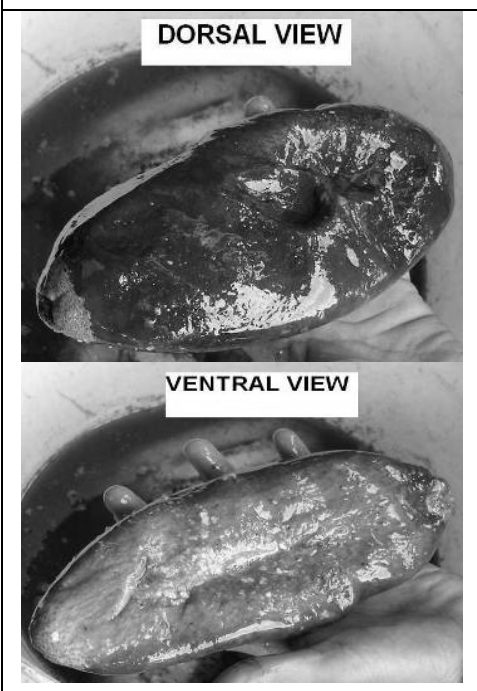

Order: Aspidochirotida Species: Actinopyga sp.2 Local Name: Bat timpu

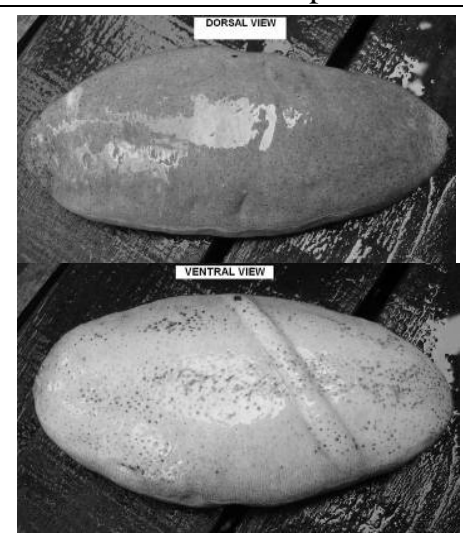

Order: Aspidochirotida Species: Actinopyga sp.6 Local Name: Bat timpu

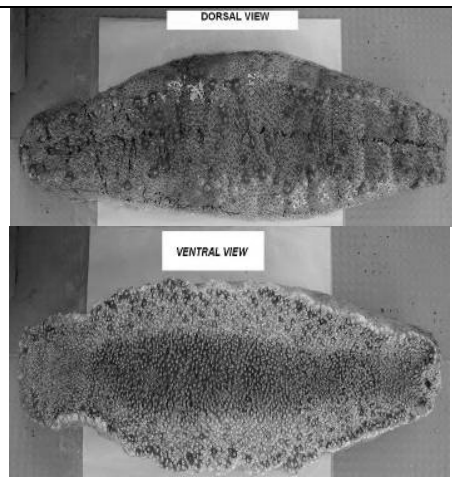

Order: Aspidochirotida Species: Stichopus sp.3 Local Name: Gamat

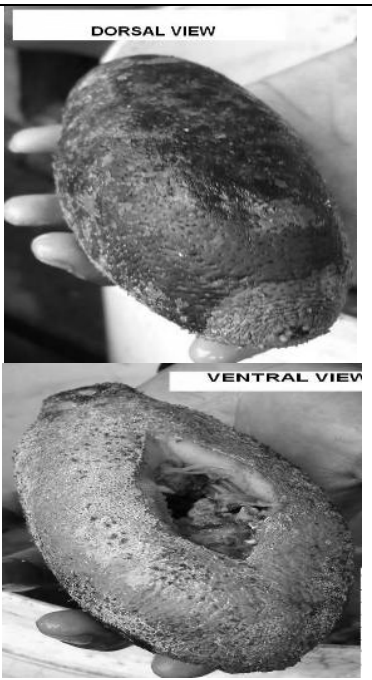

Order: Aspidochirotida Species: Actinopyga sp.3 Local Name: Bat timpu

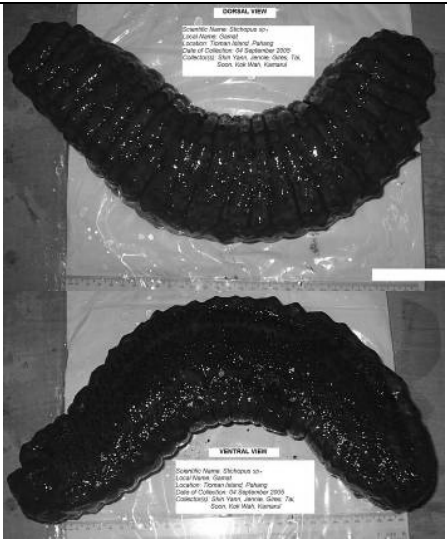

Order: Aspidochirotida Species: Stichopus sp.7 Local Name: Gamat

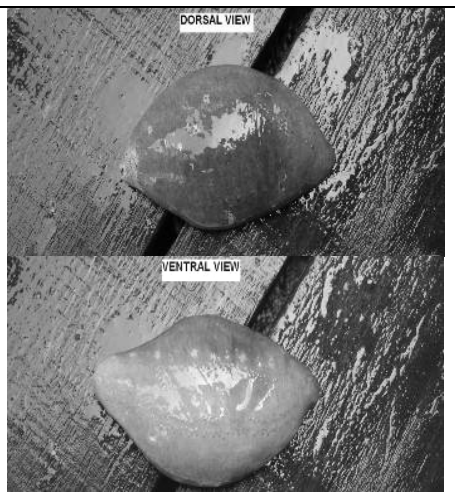

Order: Aspidochirotida

Species: : Actinopyga sp.14 Local Name: Bat timpu

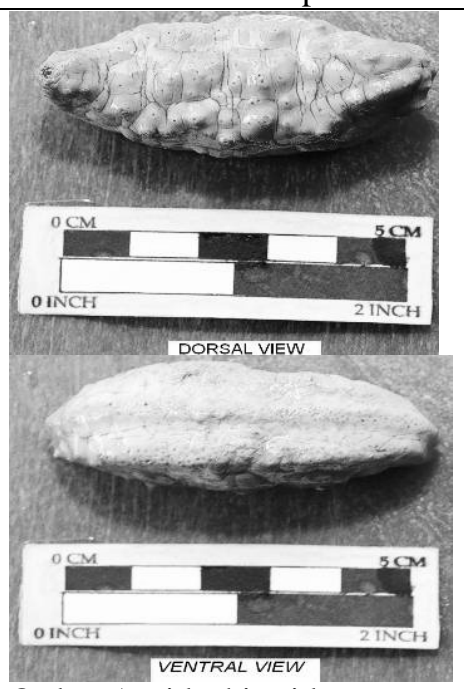

Order: Aspidochirotida Species: Stichopus sp.6 Local Name: Bat

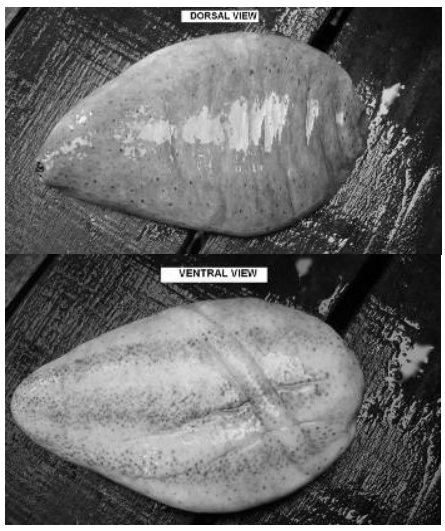

Order: Aspidochirotida Species: Actinopyga sp.7 Local Name: Bat timpu 


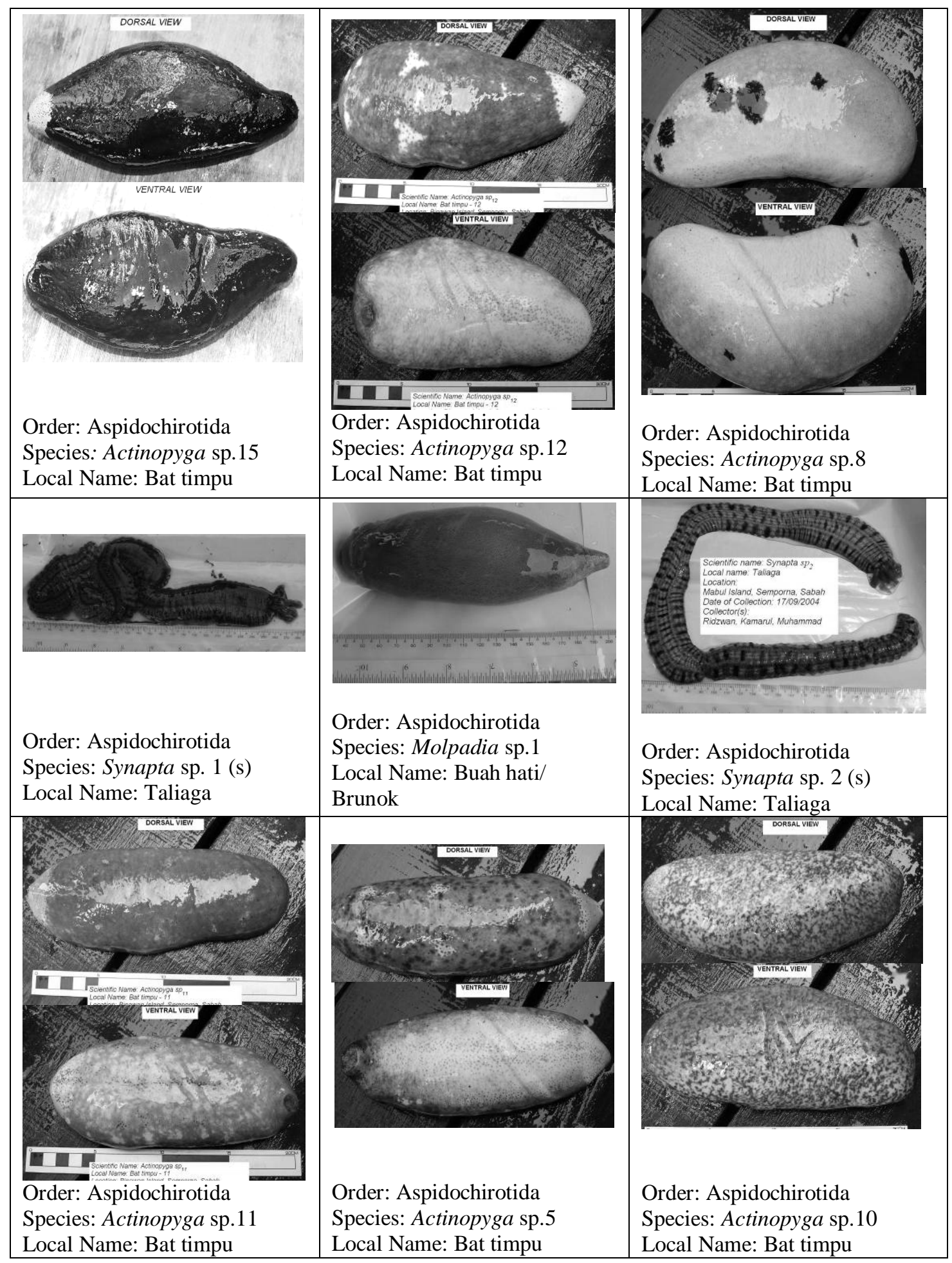




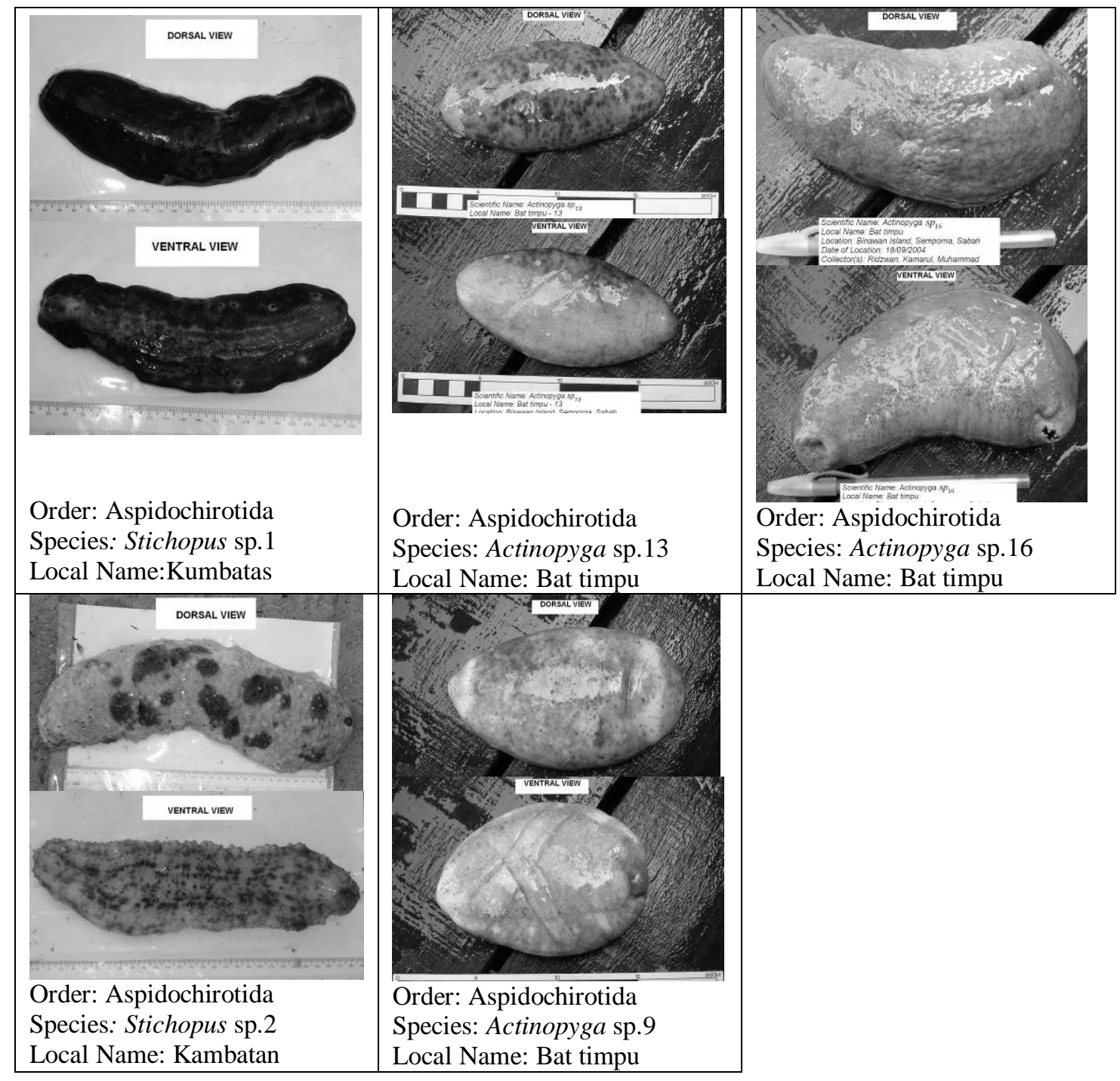

